\title{
The Terracotta Army
}

would have been happy to leave a patient fitting at home in the presence of her elderly distressed parents? Is there a point at which the duty of care to a patient who is unconscious is superseded by the duty of care to others, in this case the elderly parents? Should there be a 'get-out clause' in advanced decisions for exceptional cases where distress to others may outweigh the need to respect the patient's wishes?

How does a doctor balance duty of care to one patient who will die very soon against the duty of care to other patients? In this case an entire afternoon was taken with this scenario and the doctor's evening surgery had to be taken by another doctor. The GP in this case is usually single handed. If the other doctor had not been available, what would have happened to all the other patients seeking medical attention that afternoon? Is it right for them to suffer while the GP is involved in one particularly complicated case?

The move towards patient autonomy and against 'doctor knows best' is undoubtedly a positive one. The Mental Capacity Act 2005 clarifies many of the points that were already present under common law. In interpreting the Act, we must be aware that in not all cases will it be clear that respecting patients' decisions and acting in their best interests are the same thing, and in this case, patient autonomy is the primary concern. However, we should also remember that as doctors we are a rationed resource which needs to be shared with all of our patients.

\section{Eleanor Brown and James Pink}

The authors would appreciate feedback or comments.

\section{REFERENCES}

1. Hempsons. Consent to treatment. A brief guide for the NHS. 2nd edn. London: Hempsons Solicitors, 2007. www.hempsons.co.uk/FileServer.aspx?oID $=396 \&$ IID $=0$ (accessed 6 Mar 2008).

2. General Medical Council: Withholding and withdrawing life-prolonging treatments: good practice in decision-making. London: GMC, 2006.

DOI: 10.3399/bjgp08X280038
It was $10.10 \mathrm{pm}$ when I entered the British Museum with my booking paper printed from the internet. I was due to see the Terracotta Army at 10.20 pm, my scheduled time; visits to the exhibition being arranged like this as booking is overwhelmed, with the Museum staying open until midnight on Thursdays and Fridays.

Just entering the museum at this time, with darkness outside and the entrance and hall virtually empty, is fascinating. But watching the exhibition is spectacular; you travel back to a time when human civilisation was at its height in Egypt with the Pharaohs, in Greece, in Italy with the Etruscans and the Romans.

Three hundred years BCE ... and you enter the mysterious atmosphere where the eyes of warriors, officials, generals, dignitaries, civil managers, musicians, craftsmen, horses, and birds look at you in silence; the silence of their more than 2000 years of life in the underground and afterlife in defence of, and serving, their Emperor.

Ying Zheng was born in China in 259 BCE. At the age of 13 he became King of Qin, one of the seven main states competing for dominance and at war with each other. Under his leadership, Qin conquered the other states using highly developed weapons, technology, and military strategy. After completing his campaign, the King of Qin declared himself Qin Shihuangdi: First Divine Emperor of the Qin.

To govern his empire, the First Emperor introduced reforms and enforced strict laws. He planned to join the walls of conquered states to create a great common wall, and built new roads and canals. Standard weights and measures, a single currency, and a universal writing system (very similar to the one used today) allowed him to govern more easily. He built more than 270 palaces in his capital city Xianyang, as a display of power and to house the rulers of the states he conquered.

The First Emperor wanted to govern forever and tried many potions to prolong his life. He also spent more than 30 years building his tomb complex, a palace where he could rule forever in the afterlife. At the centre of the complex (I read it twice at the panel ... unbelievable ... $56 \mathrm{~km}^{2}$ !) lay his tomb. In 1974 a farmer digging nearby found a terracotta head. He had discovered a pit of terracotta warriors.

Around 7000 terracotta soldiers have now been found buried in three pits outside the tomb, standing guard with their imposing height, of between 185 and $194 \mathrm{~cm}$, greater than that of the real population. This is now one of the world's most important archaeological sites and London hosted part of this incredible treasure of human history.

In the exhibition, warriors continue to ward the Emperor, musicians do their work, and birds also sing to their Emperor in the afterlife. The First August Divine Emperor died suddenly at the age of $49 \ldots$ but he is still alive and ruling his $56 \mathrm{~km}^{2}$ tomb complex. Computer images render only a faint idea of the inner complex of paths and corridors for different guardians, servants, warriors, horses, and carriages ... other corridors $\ldots$ and probably rivers of mercury.

However, nobody knows what treasures it contains, even with the most sophisticated technological methods it will not be possible to know without creating ruins for the next generations. So, rest peacefully, Qin Shihuangdi, rule quietly in your afterlife, continue to govern forever ... the terracotta army will guard you safely.

\section{Francesco Carelli}

DOI: 10.3399/bjgp08X280047 